\title{
Theofilos
}

A Nordic open access journal in Theology, Philosophy and Culture

Published by NLA University College - in partnership with Johannelund School of Theology

Available at www.theofilos.no

\section{Mannen som kvinnans huvud - en exegetisk och praktisk mellanväg}

\author{
Olof Edsinger \\ Generalsekreterare för Svenska Evangeliska Alliansen \\ olof.edsinger@sea.nu
}

\begin{abstract}
Denna text har i en tidigare version publicerats i boken Olika och jämlika: Manligt och kvinnligt ur ett kristet perspektiv (Apologia förlag 2020).
\end{abstract}

Trots sitt gemensamma förtroende för Bibeln som Guds ord finns det ett antal frågor där evangelikala kristna landar i olika teologiska slutsatser. Till de mest kända hör synen på sakramenten, diverse eskatologiska frågor samt den politiska staten Israel. I den här artikeln har jag för avsikt att ge mig i kast med en annan av dessa frågor - nämligen den bibliska läran om mannen som kvinnans huvud.

Vare sig exegetiskt eller praktiskt råder det i dag någon samsyn i denna fråga, som i sin tur spiller över på det sätt vi förhåller oss till såväl äktenskap och familj som till ämbete och ledarskap i den kristna församlingen. Utan att göra anspråk på någon "slutgiltig lösning" vill jag i det följande presentera vad jag uppfattar som en mellanväg i frågan. Om inte annat kan den kanske hjälpa läsare från olika traditioner att bättre förstå de kristna som landat i en annorlunda slutsats än de själva.

\section{Fyra grundläggande frågor}

Med tanke på frågans komplexitet är det en hel del som ska hinnas med, så låt oss inte krångla till det när det inte finns något att diskutera: Nya testamentet lär oss att mannen är kvinnans huvud. Detta är budskapet i åtminstone två konkreta bibelord, och båda gångerna är det Paulus som står för formuleringarna:

\begin{abstract}
$\mathrm{Nu}$ vill jag att ni ska veta att Kristus är varje mans huvud, att mannen är kvinnans huvud och att Gud är Kristi huvud. (1 Kor 11:3)

Ni hustrur, underordna er era män så som ni underordnar er Herren. En man är nämligen sin hustrus huvud, liksom Kristus är församlingens huvud och själv Frälsare för sin kropp. Så som församlingen underordnar sig Kristus, så ska kvinnorna $i$ allt underordna sig sina män. (Ef 5:22-24)
\end{abstract}

Så här långt bör det inte vara några konstigheter: Mannen är kvinnans huvud. Men om vi därifrån tar steget till följdfrågorna, ställer sig frågetecknen snabbt på rad.

För det första: Vad betyder egentligen "huvud"?

För det andra: Vem är "kvinnan" för vilken mannen har denna roll?

För det tredje: Hur ska vi praktiskt tilllämpa det som Paulus skriver?

För det fjärde: Hur relaterar apostelns ord till Bibelns undervisning om mannen och kvinnan som jämlika?

Låt oss ta dessa frågor i tur och ordning!

\section{Vad betyder egentligen "huvud"?}

Svaret på den första frågan kan till stor del betraktas som nyckeln även till de övriga. Det är ju bara när vi vet vad "huvud" står för, som vi kan dra de prak- 
tiska konsekvenserna av apostelns undervisning i våra egna liv. Men som redan har konstaterats har det visat sig ytterst svårt för den globala kristenheten att enas om ett sådant svar. Framför allt är det två huvudalternativ som ställs mot varandra: antingen att tolka begreppet hierarkiskt eller att tolka det relationellt.

Fram till slutet av 1960-talet var det för de flesta teologer självklart att ansluta sig till den hierarkiska tolkningen. Det grekiska ordet för huvud, kefale, har i stora delar av kyrkan setts som ett uttryck för auktoritet, och på flera ställen i Gamla testamentet används ordets hebreiska motsvarighet på detta sätt (se 2 Sam 22:44; 1 Kung 8:1; Ps 18:44 m fl). ${ }^{1}$ Även i flera sammanhang där Nya testamentet talar om Jesus som huvud (se Ef 1:22; Kol 2:10) kan det tyckas självklart att det står för vår Herres auktoritet - för hans upphöjda ställning i relation till alla kosmiska makter. $^{2}$

Dock räcker det att gå tillbaka till de texter som jag inledde med för att se vissa problem med denna tolkning. Om vi börjar med Efesierbrevet 5 kan vi exempelvis konstatera att Paulus inte bara talar om kvinnans underordning under mannen, utan också om mannens kallelse till självutgivande tjänst för sin hustru. Och inte minst viktigt: han inleder sin text med att påbjuda båda parternas underordning under varandra (se Ef 5:21)! Faktum är att den enkla iakttagelsen att aposteln i vers 22-24 vänder sig direkt till kvinnorna - och alltså inte instruerar dem "via sina män" - är ett betydande avsteg från de samtida patriarkala konventionerna.

Även när det gäller Första Korinthierbrevet 11:3 finns det viktiga saker att säga. Av sammanhanget är det ju uppenbart att de tre relationsparen som lyfts fram är tänkta att uppfattas som parallella. Relationerna Kristus-varje man, man- nen-kvinnan och Gud-Kristus har helt enkelt något gemensamt som gör att Paulus väljer att ta sitt avstamp i dessa när han går till rätta med problemen vid församlingens gudstjänster. Men vid en närmare granskning framstår det faktiskt som osannolikt att parallelliteten skulle ha med auktoritetsförhaillandet i dessa relationer att göra. På detta område råder det nämligen betydande skillnader mellan vart och ett av paren! Teologen och lingvisten Cynthia Long Westfall presenterar problemet så här:

De tre paren är uppenbart tänkta att vara parallella, men de är inte parallella i fråga om auktoritetsförhållandena:

- Varje man är inte funktionellt underordnad [= tror inte på] Kristus i denna tidsålder.

- Det finns inget särskiljande sätt på vilket Kristus skulle vara en mans auktoritet men inte en kvinnas.

- Ingen man erfar den grad eller typ av underordning under Kristus som en kvinna erfar till män.

- Fadern och Sonen är ontologiskt jämlika, män och kvinnor är ontologiskt jämlika, men män är inte ontologiskt jämlika med Jesus Kristus.

- Ingen man erfar den grad eller typ av underordning som Jesus skulle erfara om han verkligen var evigt underordnad Fadern.

- Paren förklarar inte auktoritetsförhållandet mellan män. ${ }^{3}$

Mot denna bakgrund framstår det som allt annat än självklart att Paulus ärende i denna vers skulle vara att slå fast vilket auktoritetsförhållande som gäller inom de tre paren. Mer troligt är att hans poäng är något annat - förslagsvis att de alla utgör starka exempel på inbördes 
relationer, där den ena inte kan tänkas utan den andra (jfr 1 Kor 11:11-12).

Även på andra ställen i Paulus brev tycks apostelns användning av kefalē vara öppen för tolkning. Se till exempel följande texter, som alla berör Jesu relation till den kristna församlingen:

Nej, vi ska hålla fast vid sanningen i kärlek och på alla sätt växa upp till honom som är huvudet, Kristus. Av honom fogas hela kroppen samman och hålls ihop genom det stöd som varje led ger, med den kraft som är fördelad åt varje enskild del. Så får kroppen sin tillväxt och bygger upp sig själv i kärlek.

(Ef 4:15-16)

Och han är huvudet för sin kropp, församlingen. Han är begynnelsen, den förstfödde från de döda, för att han i allt skulle vara den främste. (Kol 1:18)

Han håller sig inte till honom som är huvudet och som får hela kroppen att växa med den tillväxt som Gud ger, stödd och sammanhållen som den är av leder och senor.

(Kol 2:19)

Jag vill börja med att säga att ingenting $i$ dessa verser behöver motsäga en hierarkisk tolkning av kefalē. Jesus är, och kommer alltid att vara, både huvud och Herre för sin församling. Men själva betoningen i Paulus ord tycks ändå ligga någon annanstans - nämligen på hur Kristus ger församlingen sin näring och sitt stöd. Aposteln gör därtill en explicit koppling till Kristus som församlingens ursprung, då han beskriver Jesus som "begynnelsen, den förstfödde från de döda”. Av dessa skäl tänker jag att Paulus ord kan läsas som en brygga till det som är den andra huvudtolkningen av kefalē, nämligen som "ursprung" eller "källa".

I denna betydelse kan kefale ( $\mathrm{i}$ alla fall när det används i plural) avse till exempel "huvudet" på en flod, alltså källan från vilken vattendraget har sitt ursprung. En minst lika relevant koppling är dock den som hör samman med biologiskt släktskap. Cynthia Long Westfall skriver:

Ett utmärkande sätt som kefalē förekommer på är i språket som används för familj, faderskap och släktskap. Detta inkluderar hänvisningar till stamfäder som "huvud", eftersom de är källan och ursprunget till en familjs liv (som är en biologisk relation) och eftersom deras "huvud" eller "ansikte" bär familjeidentiteten (som är genetisk). Barn får både sitt liv och sin familjelikhet från sina förfäder/föräldrar, och även från sina syskon, eftersom hela familjen är källan till ens identitet. Så både föräldrar och barn kan representeras av varandras huvud. Det är så Paulus använder kefalē: för att hänvisa till ursprunget eller källan till liv och identitet $\mathrm{i}$ kontexten av familjerelationer - man och hustru, kyrkogemenskapen som en familj, och Gud Fadern och hans Son Jesus Kristus. ... Så kefalē förekommer i samband med ledarskap, eftersom den metaforiska betydelsen av huvudet hänger ihop med auktoritetsfunktionen; men de är inte samma sak. Det finns en ordning inbyggd i metaforen, men ordningen är organisk snarare än hierarkisk. ${ }^{4}$

Om vi tar med denna relationella förståelse av "huvud" till texterna vi läste i början - Första Korinthierbrevet 11 och Efesierbrevet 5 - finner vi att anknytningspunkterna är många. Till församlingen i Korinth skriver Paulus att "mannen kommer inte från kvinnan utan kvinnan från mannen" (v 8) och "liksom kvinnan har kommit från mannen, så blir också mannen till genom kvinnan" (v 12). I båda dessa verser är det med andra ord skapelseberättelsens bild av kvinnans skapelse 
ur mannens sida (se 1 Mos 2:18-25) som utgör referenspunkten. Alltså: deras gemensamma ursprung.

Och samma sak med efesierbrevstexten. Även här tycks aposteln knyta an till Första Moseboken 2, där mannens och kvinnans gemensamma ursprung blir till en nyckel för att förklara det som är äktenskapets mysterium: De två som tidigare hörde ihop men sedan skildes åt, blir i och med förbundet förenade på nytt mannen och kvinnan blir "ett kött" (1 Mos 2:24).

Det är detta gemensamma ursprung som Nya testamentets tal om mannen som kvinnans huvud tycks vara tänkt att på ett särskilt sätt påminna om. Bibelforskaren Gordon Fee utlägger saken så här:

Paulus förståelse av metaforen, och nästan säkert den som korinthierna skulle ha uppfattat, är därför "huvud" som "källa", och mer specifikt "källa till liv".... Paulus intresse är därmed inte hierarkiskt (vem har auktoritet över vem) utan relationellt (de unika relationer som bygger på den enes egenskap av källa till den andres existens). I själva verket säger Paulus ingenting om mannens auktoritet; hans intresse ligger $\mathrm{i}$ att kvinnan är mannens ära, den utan vilken han inte är komplett. ${ }^{5}$

En detaljerad utläggning av Första Korinthierbrevet 11 skulle vara temat för en helt egen artikel. Men ovanstående kan kanske räcka för att förklara varför förståelsen av "huvud" som en relationsterm är mer (eller i alla fall minst lika) trolig än den hierarkiska förståelsen. I alla fall om vi ser till de här aktuella bibeltexterna. Själv anser jag helt enkelt att det är relationstolkningen - att mannen och kvinnan har ett gemensamt ursprung och därmed är beroende av varandra - som gör texterna mest begripliga, och som därtill gör störst rättvisa åt övriga enskildheter i
Paulus ord.

Redan nu vill jag samtidigt säga att det här inte betyder att alla tankar på att männen skulle ha ett särskilt ansvar i relation till sina hustrur måste uteslutas. Även detta tycks nämligen ligga implicit i flera av Bibelns texter på temat. I stället för "antingen-eller" tänker jag helt enkelt "både-och" när det gäller detta. 6 Paulus använder ett uttryck som knyter an till en hierarkisk struktur i hans egen samtid, och som han inte explicit väljer att ta avstånd ifrån. Men samtidigt fyller han denna struktur med ett delvis nytt innehåll, och den betydelse av kefale som ger störst rättvisa åt hans ärende blir på så sätt den relationella. ${ }^{7}$

\section{Vem är "kvinnan" för vilken mannen har denna roll?}

Vem är det då som mannen i dessa texter kan betraktas som "huvud" för? Svaret på denna fråga beror både på vilken text vi utgår ifrån, och vilken förståelse vi har av ordet kefale.

I Första Korinthierbrevet 11 ligger fokus på den gemensamma gudstjänsten, och det troliga är därför att aposteln talar om (kristna) män och kvinnor i generella termer - inte bara gifta par. Om detta stämmer skulle det alltså vara alla män i församlingen som enligt Paulus är alla kvinnors huvud, något som konkret får konsekvensen att männen ska se det som en välsignelse ("mannens ära", v 7) när kvinnorna ber och profeterar i gudstjänsten.

I Efesierbrevet 5 är situationen en annan. Här talas det uttryckligen om mannnen och kvinnan som gifta. Vad Paulus instruerar sina läsare till är alltså tänkt att praktiseras inom äktenskapsförbundet, och kan inte generaliseras till övriga relationer i församlingen. I klartext innebär detta att männen inte kan förvänta sig att 
alla kvinnor i deras närhet ska välja att underordna sig dem enligt apostelns ord. Inte heller är de själva skyldiga att älska alla kvinnor "så som Kristus har älskat församlingen och offrat sig för den" (Ef 5:25); detta påbud gäller bara i relation till deras fruar.

Värt att notera är samtidigt att Paulus ingenstans använder ordet kefale om de övriga relationerna i hushållet. När han beskriver relationen mellan männen och deras barn och slavar är det till exempel ett helt annat språkbruk som gäller. Om det finns skäl att tala om mannen som familjens överhuvud är det alltså tveksamt att knyta detta till uttrycket kefalē. Om kefalē framför allt ska tolkas hierarkiskt bör det ju även kunna användas i relation till barnen och slavarna.

\section{Hur ska vi praktiskt tillämpa det som Paulus skriver?}

Även med detta sagt kvarstår dock den svåraste frågan av dem alla. Oavsett om vi (mest) tar fasta på den hierarkiska eller den relationella tolkningen av kefale är det nämligen långt ifrån självklart hur apostelns instruktioner ska tillämpas. Till saken hör ju att Paulus själv är påfallande tystlåten angående detta!

Låt oss dock vara tydliga med vad de aktuella bibelställena inte kan betyda. Med tanke på hur Paulus ord har missbrukats behöver vi exempelvis göra klart att Nya testamentet aldrig sanktionerar våld eller förtryck i den kristna trons namn. I detta sammanhang kan det vara värt att citera den amerikanske etikern Richard Hays, som i sin utläggning av Efesierbrevet 5 slår fast:

Bilden av korset är inte tänkt att användas av dem med makt för att försäkra sig om de maktlösas undergivna lidande. Tvärtom insisterar Nya testamentet på att gemen- skapen som helhet är kallad att följa i spåren av Jesu lidande. Nya testamentets författare använder sig ständigt av korsets mönster för att kalla dem med makt och privilegier att avsäga sig dessa till förmån för de svaga (se t ex Mark 10:4245; Rom 15:1-3; 1 Kor 8:1-11:1). I Nya testamentets enda tydliga tilllämpning av detta mönster på den patriarkala äktenskapsrelationen är det männen (inte fruarna) som kallas att efterlikna Kristi exempel att ge upp sig själva i lydnad för den andres skull (Ef 5:25). Att läsa en sådan text - som kallar äkta män att älska och ömsint ta hand om sina fruar - som om det på något sätt skulle ge grund för en mans dominans eller fysiska misshandel av sin fru kan bara uppfattas som en bisarr - faktiskt rent hädisk felläsning. ${ }^{8}$

Till saken hör att den underordning som dessa texter föreskriver tycks vara tänkt att uppfattas som frivillig. Det grekiska ordet för "underordna", hypotassō, brukar nämligen inte användas när det handlar om blind eller viljelös lydnad. Åtminstone i civila sammanhang ska det i stället uttydas som att frivilligt underkasta sig, samarbeta, ta ansvar eller att bära en annan människas börda. För den som letar synonymer till apostelns ord om att underordna sig torde med andra ord "hedra" och "respektera" ligga nära till hands.

Detta framgår också av efesierbrevstexten. Paulus uppmuntrar till ömsesidig underordning med hänvisning till båda parternas "vördnad för Kristus". Kontrasten till de antika så kallade hustavlorna ${ }^{9}$ är påfallande, där bara de formellt överordnade personerna - äkta män, fäder och slavägare - instruerades om hur de skulle sköta sina respektive hushåll. ${ }^{10}$

Sammantaget menar jag att det här 
talar starkt för den relationella förståelsen av kefale. Om Paulus syfte med att använda ordet var att slå fast hierarkierna i det kristna äktenskapet, borde han ju ha kunnat använda samma ord även för de övriga relationerna i hushållet. ${ }^{11}$ Men som det nu är gör han inte det. Inte heller talar han om mannen som "familjens överhuvud" - det är bara i relation till hustrun som betoningen av mannen som "huvud" lyfts fram. Den logiska slutsatsen blir för mig att det är mannens och kvinnans gemensamma ursprung som är apostelns huvudpoäng: att kvinnan från början skapades ur mannens sida, och att äktenskapet därför är en återförening av vad som tidigare har blivit åtskilt.

Till detta kan läggas att Nya testamentet inte nämner någon enda situation då en man förväntas fatta några beslut i sin hustrus ställe. Den enda bibeltext som specifikt talar om beslut inom det äktenskapliga förbundet - nämligen i fråga om tillfällig sexuell avhållsamhet - betonar i stället betydelsen av en gemensam hållning: "Håll er inte ifrån varandra, utom möjligen för en tid med bådas samtycke för att kunna ägna er åt bönen" (1 Kor 7:5, min kursivering). Än en gång lämnas vi alltså utan vägledning kring vad begreppet kefalē kan tänkas få för praktiska konsekvenser.

Vad finns det då, utöver dessa negativa avgränsningar, att positivt säga om mannen som kvinnans huvud? Här blir det faktiskt ännu mer komplicerat, för lika tydligt som Nya testamentet är om att mannen är kvinnans huvud, lika otydligt är det om vad detta i praktiken betyder!

Vilka de ömsesidiga förpliktelserna i det kristna äktenskapet är står förhållandevis klart. Både mannen och kvinnan förväntas till exempel underordna sig varandra - alltså älska, respektera och tjäna varandra. Till detta kan läggas de generel- la ingredienserna i äktenskapsförbundet som sådant: sexuell gemenskap, sexuell trohet samt omsorg om varandras materiella behov (jfr 2 Mos 21:10-11; 5 Mos 24:1; 1 Kor 7:3-5, 33-34).

Men vad är det egentligen som är unikt för mannen? En sak har vi redan konstaterat: mannen får en betydligt tuffare arbetsbeskrivning än sin hustru. Han ska älska henne "så som Kristus älskat församlingen och offrat sig för den" (Ef 5:25). I linje med Nya testamentets generella budskap är det alltså så att den som har den starkaste ställningen är kallad till de största uppoffringarna. Och i de flesta tider och kulturer har detta varit mest tilllämpbart på mannen.

Sannolikt kan det här också kopplas till mannens fysiska övertag. "På samma sätt ska ni män leva förståndigt med era hustrur, som är det svagare kärlet”, skriver Petrus (1 Pet 3:7). Självklart finns det äktenskap där kvinnan är starkare än mannen, men genomsnittskvinnans muskelmassa uppgår bara till mellan två tredjedelar och tre fjärdedelar av genomsnittsmannens. Att detta hos de flesta män lägger grunden för en sund beskyddarinstinkt, som kan kopplas även till Nya testamentets tal om mannen som kvinnans huvud, ter sig på många sätt rimligt. Att det fysiska övertaget i många fall har missbrukats är förstås en tragisk realitet, som också hör till bilden.

Andra saker som traditionellt har inkluderats i detta ansvar är att mannen har stått för lejonparten av den gemensamma försörjningen, samt varit familjens representant i relation till (den manligt dominerade) omvärlden. Båda dessa förhållanden kan innebära såväl plus som minus, men borde alltså kunna bidra till hans roll som familjens (över)huvud.12

Samtidigt är det här en sanning med modifikation. Och då inte bara i vår egen 
tid - där många kvinnor tjänar mer än sina män - utan faktiskt också i det förflutna. I det gamla bondesamhället var det till exempel helt avgörande att mannen och kvinnan samarbetade när det gällde hemmets försörjning. Annars riskerade det gemensamma företaget att gå i stöpet. Därför kan vi också läsa i Guds ord att det är den flitiga hustrun - inte den passiva - som är sin makes stolthet (se Ords 31:10-31; jfr 12:4). För att inte tala om skapelseberättelsen, där mannen och kvinnan gemensamt tilldelas uppdraget att råda över Guds skapelse (se 1 Mos 1:26-28).

Mannen som familjens andliga överhuvud då? Ja, även denna bild är faktiskt allt annat än entydig utifrån Guds ord. Redan i Gamla testamentet har vi exempelvis texter som utmanar en sådan tankegång (se 1 Mos 16; Dom 4; Dom 13 m fl). Till saken hör också att långt ifrån alla gifta män i det antika samhället kunde titulera sig själva med "husets herre", eftersom denna roll redan tillhörde deras far eller någon annan man i storfamiljen. ${ }^{13}$ Och inte minst viktigt: tanken på mannen som ansvarig för familjens husandakt inkluderades i kyrkans lära först under senmedeltiden - efter mer än tusen år utan någon känd sådan praktik. ${ }^{14}$

Trots alla dessa nyanseringar och modifieringar vill jag dock inte avfärda tanken på att mannen har blivit anförtrodd ett specifikt ansvar inom den egna familjen. För detta finns det nämligen både teologiska och historiska skäl. De teologiska har - än en gång - med ordet "huvud" att göra. För även om jag tror att den primära poängen när Paulus använder detta har med mannens och kvinnans beroende av varandra (snarare än mannens hierarkiska överordning) att göra, tycks det åtminstone indirekt finnas en hierarkisk dimension i begreppet. Inte ontologiskt, i meningen att mannen skulle vara mer värd än kvinnan, utan funktionellt. Om apostelns enda syfte med att tala om mannen som kvinnans huvud var att säga att "mannen och kvinnan hör ihop" tycker jag helt enkelt att han borde ha valt ett annat språkbruk, som inte på samma sätt smakar "skapelseordning".15

En annan text att knyta an till kan i detta sammanhang vara berättelsen om Israels exodus, där Herren ger Mose och Aron följande instruktioner:

Säg till hela Israels församling: På tionde dagen i denna månad ska varje familjefar ta sig ett lamm, så att varje hushåll får ett lamm. Men om hushållet är för litet för ett lamm, ska familjefadern och hans närmaste granne ta ett lamm tillsammans efter antalet personer. För varje lamm ska ni beräkna ett visst antal, efter vad var och en äter. Ett felfritt, årsgammalt lamm av hankön ska ni välja ut och ta antingen från fåren eller getterna. Ni ska förvara det till den fjortonde dagen i denna månad. Då ska hela Israels församlade menighet slakta det i skymningen. (2 Mos 12:3-6)

Har dessa instruktioner något att säga till oss i dag? Därom tvista de lärde. Men det minsta man kan säga är ju att Gud i denna text knyter an till den samtida ordningen med mannen som familjens (andliga) överhuvud.

Någonstans tänker jag också att berättelsen om syndafallet borde spela in här. Även om det var Eva som syndade först, är det nämligen slående att det var Adam som först ställdes till svars av Herren. Kan vi i detta ana någon form av ansvarslinje - att Gud hade förväntat sig att Adam skulle skydda sin familj från vad som skedde? 16 Och om så är fallet: kan det vara så att det primärt är de förtryckande aspekterna av den manliga över- 
ordningen som kom in i skapelsen med synden - inte överordningen i sig? För mig är i alla fall detta en möjlighet att överväga. ${ }^{17}$

Om vi därifrån går över till de mer historiska argumenten knyter det första av dessa an till en realitet som vi i dagens västerländska samhälle tenderar att glömma bort: Under större delen av mänsklighetens historia har familjen varit att betrakta som en produktionsenhet - alltså ett mindre företag. Som sådan har den också varit i behov av arbetsledning, och åtminstone på ett övergripande plan har det normalt varit mannen som haft detta ansvar. Maggie Gallagher, direktor för Institute for Marriage and Public Policy $\mathrm{i}$ Washington, D.C., skriver:

Aristoteles, Paulus och i princip alla människor under två tusen år förutsatte att familjer behövde huvud av samma skäl som vi i dag utan förbehåll accepterar tanken på att företag behöver huvud [= chefer]. Under merparten av mänsklighetens historia ... var familjerna den primära produktionsenheten. Man, hustru, mindre barn, ogifta syskon, tjänare och lärlingar såväl som åldrande vuxna var beroende av varandras arbete för maten de åt och kläderna de bar. Att koordinera en mängd individers producerande aktiviteter var en avgörande nödvändighet, där insatsen inte kunde vara högre: om familjen misslyckades med att gemensamt producera tillräckligt att äta, skulle de svälta. ${ }^{18}$

Längre fram i sin artikel sätter Gallagher fingret på två andra fenomen, som i alla tider har kunnat skönjas när det gäller mannens relation till sin familj. Nämligen för det första: Både hushållet och barnuppfostran är områden där kvinnan har det naturliga försteget i relationen till sin man. Och för det andra: I alla tider har männen varit frestade att förverkliga sig själva på andra arenor än det egna hemmet. Det må vara jobbet, hobbyn, puben eller andra delar av "männens värld", och gemensamt för dem alla är att männen där har känt sig tryggare och mindre kringskurna än i sina egna familjer.

Bristen på jämställdhet därhemma blir ofta tydligast i föräldraskapet. Kvinnan har det naturliga försteget $\mathrm{i}$ relation till sina barn eftersom hon genom graviditet, förlossning och amning har fått en särskild typ av band till dessa. Men inte bara det, för samma sak kan ofta sägas om hushållet i stort. Maggie Gallagher skriver:

För många män innebär det gifta livet en erfarenhet av underordning under kvinnans domäner: av tillgivenhet, ordning, kärlek, bebisar ett liv i tjänst för andra, en daglig omgång av plikter utan ärofyllda sista motståndsfickor. De ociviliserade manliga dygderna måste förändras i grunden, om inte överges helt, om män ska kunna fungera som äkta män och fäder. ...

I sin mest grundläggande form erbjuder rollen som huvud männen en ursäkt att underordna sig familjelivets plikter - och den realitet där kvinnor behåller betydande makt, kontroll och auktoritet i hemmet över det dagliga livet och över mannen. En man i denna situation noterar sannolikt att "jag fattar alla de stora besluten och hon fattar de små; det lustiga är bara att på 45 år har det ännu inte dykt upp några stora beslut". Traditionellt har frun (som kanske, men inte nödvändigtvis, även arbetar utanför hemmet) beslutat vad familjen äter, vad den har på sig, i många fall var den bor (till exempel beroende av vilket skoldistrikt eller lokalsamhälle som är lämpligast för barnen), var den semestrar, vilket slags barnomsorg som är mest lämplig ... och hur de dagliga hushållsrutinerna ska se ut. ${ }^{19}$ 
Sammantaget, skriver Gallagher vidare, leder detta till att en man "i praktiken förlorar ... kontrollen över hela sin lön, liksom sin fritid, när han väljer att gifta sig”. Och: "För varje fru som är beroende av sin man för huvuddelen av familjens inkomster, finns det en man som är beroende av sin fru för att ge honom ett hem och en familj och till och med ett existensberättigande. Trots detta avsäger sig männen helt frivilligt denna grad av makt innanför äktenskapet, utan att känna sig underordnade." 20

Gallaghers analys är förstås präglad av en amerikansk medelklasskontext. Men hennes iakttagelser är nog mer universella än vi kanske spontant tänker oss. Påfallande mycket går till exempel att applicera även på skandinaviska förhållanden. Och hennes huvudpoäng, som alltså är skälet till att jag citerar henne, är att talet om mannen som kvinnans (eller familjens) huvud har en strategisk funktion som går utöver att mannen och kvinnan behöver hjälpas åt i största allmänhet. Gallagher igen:

Så snart vi tar familjen på allvar som en viktig arena i livet, kan vi erkänna att behovet av en kulturellt skapad mansroll i familjen bygger på kvinnans naturliga överlägsenhet på denna arena ... [Många] som förordar jämställdhet mellan könen tilllåter visserligen män och hustrur att göra olika saker inom äktenskapet, men de slår till reträtt inför tanken på att ens kön borde påverka dessa beslut. Män kan ha en tjänande roll inom familjen, men egentligen inte en manlig roll. ${ }^{21}$

Kanske är det just här som skon klämmer. När vi helt släpper tanken på mannen som kvinnans/familjens huvud, släpper vi lätt tanken på att mannen som man har något särskilt att bidra med i det gemensamma hushållet. Det måste naturligtvis inte vara så, men givet kvinnans naturliga försteg, och givet frestelsen för många män att förverkliga sig själva utanför hemmets väggar, är det kanske inte fel att hålla fast vid denna tanke trots allt? Talet om mannen som kvinnans huvud är ett bemyndigande av mannen som en betydelsefull person i vad som ofta tenderar att vara "hustruns domäner".

\section{Hur relaterar apostelns ord till Bibelns undervisning om mannen och kvinnan som jämlika?}

Den sista av mina inledande frågor kan kanske redan betraktas som besvarad. Ingenting av det jag hittills har skrivit behöver ju kasta någon skugga över tron på mannen och kvinnan som lika mycket värda, eller på att de har lika mycket att bidra med i relation till varandra. I alla fall inte så länge vi förkastar den i feminismen så vanliga tanken på likhet som en förutsättning för jämlikhet.

Som vi har sett finns det också någon form av spänning i det bibliska materialet. Å ena sidan är det påfallande att kvinnan oftare än mannen uppmanas till underordning; å andra sidan slår Paulus fast att kallelsen till underordning är ömsesidig (se Ef 5:21). Klart är att i den mån som mannen kan sägas ha någon form av företräde - vilket jag alltså menar att han i vissa avseenden har, till exempel genom sitt fysiska och (ofta) ekonomiska övertag - ska detta förvaltas genom den typ av tjänande ledarskap som Jesus själv utgjorde det bästa exemplet på (jfr Ef 5:21-33).22

$\AA$ andra sidan har vi sett att det i relation till hus och hem ofta är kvinnan som har det naturliga företrädet. Och det är alltså utifrån detta som jag anser att Maggie Gallaghers ord om att ge mannen en tydlig roll $\mathrm{i}$ hemmet är värda att begrunda. Effekten av en sådan hållning menar 
jag nämligen blir just ökad jämställdhet, i ett läge där mannen tenderar att börja på minus och kvinnan på plus.

Värt att notera är också att inga av de bibeltexter som vi har läst uttalar sig i frågan om mannens och kvinnans relationer i samhället i stort. Att mannen är kvinnans huvud inom äktenskapsförbundet säger alltså ingenting om hur det borde vara i exempelvis näringslivet eller politiken. Nya testamentet uttalar sig helt enkelt inte om dessa arenor! Mycket tyder i stället på att Paulus betraktade detta som icke-frågor. Klart är att han omgav sig av ett antal kvinnor som hade framträdande roller såväl i församlingen som i det samtida näringslivet (se Apg 18:1-3; Rom 16 $\mathrm{m} \mathrm{fl})$.

I någon mån får man kanske också säga att Nya testamentets författare är realister när det gäller detta. De fokuserar helt enkelt på de arenor som ligger inom deras eget mandat att påverka. Att kyrkan "trots" detta fick så starkt inflytande även på den grekisk-romerska kulturen handlade om kyrkans explosionsartade tillväxt, snarare än om ett uttalat politiskt program. Revolutionen kom underifrån från marginalerna - och det är svårt att förneka urkyrkans karaktär av motkultur. $^{23}$ Som Cynthia Long Westfall skriver:

Snarare än att etablera en form av manlig auktoritet som skulle omdana det grekisk-romerska samhället, instruerade Paulus den kristna gemenskapen att verka inom samhällets konventionella auktoritetsstrukturer.

Inom kyrkan, däremot, var auktoritetsstrukturen för både män och kvinnor helt annorlunda jämfört med hemmet och det offentliga rummet. Den tidiga kyrkan talade nästan ett annat språk: som jämlika arvtagare var män och kvinnor bröder och systrar. Alla sedvänjor som byggde på kategorier som position och privilegium var borttagna. Gud var de troendes ende beskyddare, och Jesus Kristus den ende medlaren. Ingen annan än Gud var gemenskapens fader.

$\AA$ andra sidan kan Paulus vara en far för de kyrkor som han har planterat, eller fungera som mentor, samtidigt som han har gjort sig själv till allas slav. En ledare ska respektera alla de äldre troende som sina egna fäder och mödrar (1 Tim 5:1-2), samtidigt som ledarna beskrev sig själva med lågstatustitlar som "slav", "tjänare" och "herde". 24

Ett bra exempel på ovanstående hållningar kan vara Petrus ord i Första Petrusbrevet, som till stor del knyter an just till de samtida auktoritetsstrukturerna. Först ger aposteln en mer generell uppmaning till de troende att underordna sig de politiska makthavarna:

Underordna er alla mänskliga myndigheter för Herrens skull, både kejsaren som högste härskare och ståthållarna, som är sända av honom för att straffa dem som gör det onda och hedra dem som gör det goda. Det är Guds vilja att ni genom att göra gott ska tysta munnen på oförståndiga och okunniga människor. Ni är fria, men använd inte friheten som täckmantel för det onda utan för att tjäna Gud. Visa aktning för alla, älska era trossyskon, vörda Gud och ära kejsaren. (1 Pet 2:14-17)

Samma typ av uppmaning riktas sedan specifikt till dem av Petrus läsare är slavar:

Ni slavar, underordna er era herrar och visa dem all respekt, inte bara de goda och milda utan även de hårda. Det är en nåd när någon är medveten om Gud och därför håller ut när han får lida oskyldigt. 
Vad är det värt för beröm om ni står ut med straff när ni syndar? Men om ni står ut med att lida när ni gör det goda, då är det en nåd inför Gud. Till detta är ni kallade. Kristus led i ert ställe och efterlämnade ett exempel åt er, för att ni ska följa i hans fotspår. (1 Pet 2:18-21)

Apostelns ord kan på många sätt vara svårsmälta. Men de ligger helt i linje med vad vi tidigare har läst i Paulus brev, och i likhet med sin kollega hänvisar Petrus till Herren själv som förebild för det beteende han förordar. Som Guds barn ska vi - precis som Jesus Kristus - leva oklanderligt, i sund vördnad för dem vi har över oss. Samtidigt är Petrus tydlig med att vi inte ska lyda våra överordnade $\mathrm{i}$ fruktan - utan i kärlek. Ytterst sett tjänar vi nämligen inte någon människa, utan Kristus själv (jfr Kol 3:23). Som Martin Luther uttrycker det hela i Om en kristen människas fribet: "En kristen människa är den friaste herre över allting och ingen underdånig. En kristen människa är den tjänstvilligaste tjänare under allting och alla underdånig." 25

Samma tankegång möter oss i Petrus ord till de äkta paren:

På samma sätt ska ni hustrur underordna er era män, så att även de män som inte vill tro på ordet kan vinnas utan ord genom sina hustrurs liv, när de ser hur gudfruktigt och rent ni lever. Er prydnad ska inte vara yttre ting som konstfulla håruppsättningar, påhängda guldsmycken eller fina kläder, utan hjärtats fördolda människa med den oförgängliga skönheten hos en mild och stilla ande. Det är mycket dyrbart i Guds ögon. Så smyckade sig också förr de heliga kvinnorna som satte sitt hopp till Gud. De underordnade sig sina män, så som Sara lydde Abraham och kallade honom herre. Hennes barn har ni blivit när ni gör det som är gott och inte låter er skrämmas. På samma sätt ska ni män leva förståndigt med era hustrur, som är det svagare kärlet. Visa dem aktning som medarvingar till livets nåd så att inget står $i$ vägen för era böner. (1 Pet 3:1-7)

Än en gång ser vi här att kallelsen till de gifta kvinnorna att underordna sig sina män upprepas. Men syftet med detta är inte att de ska "veta sin plats" eller vara allmänt kuvade. Tvärtom skriver Petrus att de vandrar i gudskvinnan Saras fotspår när de gör det som är gott och inte låter sig skrämmas. Som avslutning vänder han sig därtill till de troende männen och låter dem förstå att om de inte behandlar sina fruar med respekt, kommer det att få konsekvenser för deras egen gudsrelation. Det är när mannen och kvinnan står enade - och, ja, underordnar sig varandra - som inget ska stå i vägen för deras böner.

Sen är det förstås sant att det även står att "Sara lydde Abraham och kallade honom herre". Men frågan är ändå om detta behöver tolkas som en generell uppmaning: "Gud vill att fromma kvinnor ska lyda sina män!” En betydligt troligare tolkning menar jag själv är att Petrus vill hjälpa de kvinnor vars män "inte vill tro på ordet”, och som förväntar sig att deras fruar ska agera i enlighet med dåtidens patriarkala mönster, att hitta ett förhållningssätt till sina män som gör att de "kan vinnas utan ord genom sina hustrurs liv”.26 En lämplig förebild skulle i så fall kunna vara just Abrahams hustru Sara, som enligt den apokryfa skriften Abrahams testamente uttryckte sig på detta sätt.

Sammantaget menar jag därför att det är fel att säga att Nya testamentets tal om mannen som kvinnans huvud står i kon- 
flikt med samma Bibels tal om jämlikheten mellan könen. Den stora förändringen har förvisso inte med relationen till överheten att göra utan med relationerna inom församlingen. Dock skulle det inte dröja särskilt länge förrän dessa fick konsekvenser även för samhället i stort. Ju fler människor som anslöt sig till den kristna kyrkan, desto svårare blev det nämligen att upprätthålla romarrikets hierarkier. Inte minst gällde detta i fråga om slaveriet, som i praktiken blev omöj- ligt att behålla i sin ursprungliga form när kyrkans inflytande växte.

Ömsesidig underordning må alltså vara mindre revolutionärt än den könskamp och det socialistiskt inspirerade "ressentiment" som präglar stora delar av dagens feministrörelse - men i längden har det en makt, inte bara att reformera strukturer, utan också att reformera hjärtan. Och det är väl just detta som det kristna evangeliet handlar om?

\footnotetext{
Noter

${ }^{1}$ Detta gäller då det hebreiska ordet rōsh, som på några - men långt ifrån alla - ställen i den grekiska LXX översätts med kefale.

2 Innebörden i ett av dessa ställen modifieras dock av Cynthia Long Westfall: ”Poängen i Kolosserbrevet 2:10 är att Kristus är källan till den troendes fullhet på samma sätt som han är huvudet (källa och upprätthållare) till varje härskare och makt. Denna innebörd görs klarare av att Paulus redan med emfas har fört fram denna poäng i Kolosserbrevet 1:15-17, som explicit inkluderar makterna i 2:10 ... Hänvisningen till Jesus som huvudet över härskarna och makterna kan därför låta som att den syftar på hans makt över dem, men både avsnittets poäng och dess nära kontext indikerar faktiskt att det betyder att han är deras källa - det vill säga, deras skapare." (Paul and Gender: Reclaiming the Apostle's Vision for Men and Women in Christ, Baker Academic 2016, s 81-82.)

3 Long Westfall, Paul and Gender, s 87.

4 Ibid, s 82-83.

5 Gordon D Fee, NICNT: The First Epistle to the Corinthians, Eerdmans 1987, s 503-504. Mot detta kan man förstås invända att uttrycket "huvud" i sig förutsätter någon form av auktoritetsförhållande - även om det inte råkar vara detta som Paulus primärt fokuserar på. Men det förtar inte att Fee kan ha rätt i fråga om betoningen. 6 Jfr den kände bibelforskaren och komplementarianen Craig Blomberg ord: ”Efter tidigare anklagelser på båda sidor om att ordet aldrig betydde vad den andra sidan hävdade att det gjorde, finns det en växande konsensus om att det åtminstone finns en handfull olika betydelser av kefale som antingen primärt betyder 'auktoritet' eller 'källa'. Vad som inte har demonstrerats är dock att singularisformen ... någonsin betyder 'källa' utan att samtidigt inbegripa någon form av auktoritet." (Stanley N Gundry och James R Beck, red, Two Views on Women in Ministry, Zondervan, reviderad utgåva 2005, s 155-156.) Även Anthony Thiselton talar i sin kommentar NIGTC: The First Epistle to the Corinthians (Eerdmans 2000) om begreppet huvud som ett "polymorft koncept" med "mångfaldiga betydelser från en kontext till en annan" (s 820).

7 Som Michelle Lee-Barnewall skriver i Neither Complementarian nor Egalitarian: A Kingdom Corrective to the Evangelical Gender Debate (Baker Academic 2016): "Den normala förväntan utifrån metaforen är att huvudet är kroppens ledare och försörjare. Följaktligen är det huvudets ansvar att trygga sin egen säkerhet och kroppens ansvar att offra sig själv för huvudets skull. Till följd av detta skulle vi förvänta oss att Paulus instruerade hustrun, kroppen, att vara villig till offer för mannens skull, huvudet. Sådana instruktioner vore de mest logiska eftersom kroppen, enligt det gängse resonemanget, inte kunde överleva utan huvudet. Men det är inte detta vi finner; snarare slår Paulus fast det motsatta” (s 156-158).

Längre fram fördjupar Lee-Barnewall sitt resonemang utifrån syndafallsberättelsen: "I syndafallet distanserade sig Adam från Eva genom att skylla på henne snarare än ge uttryck för en sann förening som 'ett kött'. I stället för att ta ansvar för sin egen överträdelse, var han i grunden villig att offra henne genom att försöka lägga skulden på henne och samtidigt rädda sig själv (1 Mos 3:12). Därmed visade han på motsatsen till den attityd som förväntas av en äkta man i Kristus. I Efesierbrevet skapar mannen/Kristus intimitet genom att visa lika mycket omsorg om hustrun/kyrkan som om sig själv och ger på så sätt den näring och omsorg som behövs för en intim förening. [...] Den som normalt skulle förväntas tjäna blir en mottagare av tjänande kärlek” (s 163-164).

8 Hays, The Moral Vision of the New Testament: A Contemporary Introduction to New Testament Ethics (HarperCollins 1996), s 197.

9 Uttrycket "hustavla" är i dag främst förknippat med Martin Luther, som i ett appendix till Lilla katekesen beskriver hur husfolkets inbördes förpliktelser är tänkta att regleras. Men som framgår av nästa not har konceptet en betydligt längre historia, som åtminstone sträcker sig tillbaka till Aristoteles (384-322 f Kr).
} 
${ }^{10}$ Ett citat ur Aristoteles inflytelserika verk Den nikomachiska etiken kan tjäna som exempel: "Sambandet mellan far och son innehåller grunddragen för ett kungadöme. Omsorgen om barnen går ju tillbaka på fadern [... ] Likaså är husbondens förhållande till slavarna tyranniskt, eftersom det här är fråga om att främja hans intressen. [...] Förhållandet mellan man och hustru tycks närmast vara aristokratiskt. Mannen härskar här efter förtjänst och bestämmer om sådant som ankommer på honom. Men det som lämpar sig för hustrun överlåter han åt henne.” (Aristoteles, Den Nikomachiska etiken, Daidalos, tredje upplagan 2012, s 244.)

11 Man kan förstås invända att barn och slavar är tvungna att lyda sina föräldrar/ägare, medan det i fruarnas fall handlar om en frivillig underordning (som dock även den yttrar sig i lydnad, jfr 1 Pet 3:5-6). Men då glömmer man att det i den antika världen var en självklarhet att alla i ett hushåll skulle lyda sin pater familias. Hur man än vrider och vänder på det måste därför Paulus formuleringar stå för något annat än vad som redan var gängse - och därmed självklart - i den samtida kulturen.

12 Till detta kan även läggas ett antal historiska omständigheter, som i ännu lägre grad kan föras över på situationen i Sverige i dag. Som William Webb skriver i Ronald W Pierce och Rebecca Merrill Groothuis (red), Discovering Biblical Equality: Complementarity Without Hierarchy (InterVarsity Press 2005): "Det finns flera skäl för att dessa påbud [till kvinnor om att underordna sig sina män] var begripliga i sin ursprungliga kultur: skillnader i de giftas åldrar (kvinnan var ofta betydligt yngre), skillnader i mängden formell utbildning, skillnader i möjligheterna att förvärva och behålla resurser, brist på informationsresurser inom hemmet, kvinnors avsaknad av social exponering. Dessa och andra ickemoraliska pragmatiska faktorer skapade en automatisk och ganska tung hierarki” (s 398).

13 Cynthia Long Westfall skriver: "Den moderna västerländska kärnfamiljen existerade inte i den grekiskromerska kulturen. Få män åtnjöt familjeöverhuvudets status. Detta var statusen hos män i den romerska kulturen som tillhörde eliten och som hade denna rättighet inom storfamiljen. Även om vi accepterar förståelsen av 'huvud' som 'auktoritet' skulle patriarken i storfamiljen vara det enda 'huvudet' i det första århundradets sammanhang. Denna individ skulle ungefär motsvara 'gudfadern' i moderna filmer och böcker om maffian.” (Paul and Gender, s 174-175.)

14 Som Daniel Mark Cere skriver i David Blenkenhorn, Don Browning och Mary Stewart Van Leeuwen (red), Does Christianity Teach Male Headship? The Equal-Regard Marriage and Its Critics (Eerdmans 2004): "I det fjortonde och femtonde århundradet började ett mer avgörande 'teologiskt' förhärligande av den patriarkala auktoriteten dyka upp. 1400-talets äktenskapsmanualer ger en starkare betoning av mannens centrala roll i hemmet som herre, andlig vägledare och utbildare. Renässansens katolicism visar sig vara betydligt mer ideologiskt patriarkal än medeltidens katolicism. Äktenskaplig enighet och trohet tonas ned till förmån för äktenskaplig auktoritet.

Till en del tycks denna utveckling vara resultatet av devotio moderna-rörelsens (modern andakt) översättning av monastiska auktoritetsmodeller för det 'heliga hushållet'. Det manliga överhuvudet tilldelas nu abbotens religiösa funktioner och andliga auktoritet. Ansvaret för andlig vägledning, undervisning och att leda familjen i bön läggs till mannens mer traditionella administrativa uppgifter. För hustrun är lydnad inte längre enbart etiskt korrekt utan en andligt förlösande handling” (s 104).

15 Den enklaste förklaringen till Paulus val av ordet kefale är antagligen att han gjorde bruk av ett begrepp som var etablerat i den rådande kulturen, men att han därefter fyllde det med ett delvis annat innehåll än vad som var gängse. I den antika världen ansåg man verkligen att mannen var ontologiskt överordnad kvinnan - men som vi har sett är denna tanke frånvarande i Nya testamentet.

16 Samtidigt som jag håller denna tolkning för trolig, vill jag dela med mig av tre goda motargument från Richard Hess i Discovering Biblical Equality: "För det första var det mannen som först mottog befallningen om att inte äta. För det andra spegelvänder förhöret i Första Moseboken 3:9-13 den ordning som karaktärerna introduceras i Första Moseboken 3:1-8. Sådana koncentriska eller kiastiska konstruktioner är framträdande i hebreiska berättelser, och särskilt i Första Moseboken. Kiasmen fullkomnas i Första Moseboken 3:9-13 genom det omvända framträdandet av mannen, kvinnan och ormen. I centrum av denna kiasm står Gud, på vilken berättelsen och det senare förhöret hänger. För det tredje måste Gud fråga ut mannen och kvinnan var för sig för att de ska kunna visa den grad i vilken deras synd har orsakat en förlust av harmoni i deras partnerskap" (s 90).

17 Det finns förstås fler tänkbara argument för en mer traditionell hållning, även om jag själv förhåller mig skeptisk till de flesta av dessa. Wayne Grudem ger exempelvis tio olika skäl för varför han och andra komplementarianer förordar en hierarkisk förståelse av mannen som kvinnans huvud (Countering the Claims of Evangelical Feminism, Multnomah Publishers 2006, s 21-24):

1) Den ordningen i vilken mannen och kvinnan skapades (1 Mos 2:7, 18-23).

2) Det faktum att Adam - inte Eva - står som representant för mänskligheten som helhet (1 Kor 15:22 m fl).

3) Det är Adam som får uppdraget att namnge sin fru (1 Mos 2:23).

4) Gud namnger hela mänskligheten utifrån mannen (1 Mos 5:1-2).

5) Det var Adam som först ställdes till svars efter syndafallet, trots att det var Eva som begick den första synden (1 Mos 3:1, 6).

6) När Gud skapade Eva, var det för att hon skulle vara mannens "medhjälpare" (1 Mos 2:18). 
7) Syndafallet perverterade de befintliga rollerna mellan mannen och kvinnan - inklusive Adams överordnade ställning. Det var alltså inte synden som orsakade denna rollfördelning (1 Mos 3:16).

8) Evangeliet upphäver syndafallets förbannelse, men inte hierarkin inom det kristna äktenskapet (Kol 3:18-19).

9) Mannens roll i äktenskapet motsvarar Jesu roll i relation till sin församling (Ef 5:31-33).

10) Jämlikhet, skillnader och enhet står inte i motsats till varandra. Samma sak kan sägas om Guds treenighet, som är förebilden för Paulus undervisning om mäns och kvinnors relation till varandra (1 Kor 11:3).

18 Maggie Gallagher, "Reflections on Headship" i David Blenkenhorn, Don Browning och Mary Stewart Van Leeuwen (red), Does Christianity Teach Male Headship? The Equal-Regard Marriage and Its Critics (Eerdmans 2004), s 114.

19 Ibid, s 118-119.

20 Ibid.

21 Ibid, s 120-121.

22 Som Anthony Thiselton, som själv lutar åt den hierarkiska tolkningen, uttrycker det: "Ännu mer slående än kopplingar mellan källa och bruket av Första Moseboken 2 i den omedelbara kontexten är det sammantagna perspektivet i 1 Kor 8:1-14:40 att Paulus bestyrker den teoretiska rätten hos de 'starka' eller 'framstående' att utöva sin 'kunskap' och 'frihet', men på ett dramatiskt sätt placerar gränser och kvalifikationer runt fribet och kunskap genom att insistera på kärlekens primat (som i 1 Kor 13:1-13) ... Om Paulus förfäktar en teoretisk hierarki, något som helt klart korresponderar mot 'kunskap' om skapelseordningen, måste den främste inom denna ordning skydda statusen och självrespekten hos 'de svaga' för vilka de måste ta ansvar." (The First Epistle to the Corinthians, s 821.)

23 För en fortsatt utläggning av detta, se Rodney Starks bok The Rise of Christianity: How the Obscure, Marginal Jesus Movement Became the Dominant Religious Force in the Western World in a Few Centuries, Princeton University Press 1996.

24 Long Westfall, Paul and Gender, s 249-250. Med tiden blev det tyvärr så att det sekulära samhällets värderingar i stället kom att påverka kyrkan och dess interna ledningsstrukturer. Men det är en annan historia.

25 Martin Luther, Om en kristen människas frihet (Verbum 1994), s 5.

26 Som professor emeritus Birger Olsson uttrycker det i sin kommentar till Första Petrusbrevet: "Den patriarkaliska husordningen som sådan är inte författarens tema här. Den legitimeras inte, den kritiseras inte. Den bildar endast ram till ett mönster för en rätt kristen livshållning. ... Uppmaningar till hustrurna att underordna sig möter ofta i NT med skilda motiveringar. Unikt för 1 Petr är missionsmotivet” (KNT, EFS-förlaget 1982, s 126). 